\title{
Xi Jinping's Party Development Ideology and Its Enlightment on Party Development in Public Hospitals
}

\author{
Rujun Cai
}

\author{
Public Health School, Fujian Medical University, Fuzhou, 350122, China \\ Corresponding author's Email:ghy2680750@163.com
}

\begin{abstract}
In face of the pandemic, Party development in public hospitals has become increasingly important. The Party Central Committee has always attached importance to Party development in public hospitals, and President Xi Jinping has given instructions on the Party building in public hospitals and the ideological work of Party members in hospitals for many times to clarify the important status and task requirements of the Party development in public hospitals. In this thesis, through discussing the problems of Party building work in public hospitals and the revelation of Xi Jinping's Party development ideas on Party development in public hospitals, we conduct research and analysis to explore the establishment of a long-term mechanism for Party building work in hospitals, aiming to provide some feasible theoretical guidance to improve the level of Party building work in hospitals and further promote the Party building work of health care workers.
\end{abstract}

Keywords: Xi Jinping, Party development, public hospitals

\section{INTRODUCTION}

The management of public hospitals face great challenges because of the global coronavirus pandemic, and vulnerabilities in the management of public hospitals are to be addressed. In this context, the in-depth study of Party development philosophy of General Secretary Xi Jinping in the new era can inspire the Party development in public hospitals. At present, a lot of studies have been conducted in the academic field on Xi Jinping's Party development philosophy and the Party development in public hospitals respectively, but the exploration of the enlightment of $\mathrm{Xi}$ Jinping's Party development philosophy on the Party development in public hospitals is far from enough. Therefore, this paper attempts to study from the perspective of the guidance of Xi Jinping's Party development philosophy on Party development in public hospitals, with a view to solving the management problems faced by public hospitals.

\section{THE MAIN CONTENT OF XI JINPING'S PARTY DEVELOPMENT PHILOSOPHY}

General Secretary Xi Jinping has emphasized the importance of Party building on several occasions and put forward a series of ideological views, which are summarized below.
First, ideological development.

Practice is guided by knowledge. Party development requires that all Party members must unify their ideological understanding. General Secretary Xi Jinping took the collapse of the Soviet Union and the dramatic changes in Eastern Europe as examples to elaborate on the consequences of defective ideological development and the slippage of ideals and beliefs. Under any historical conditions and in any place, Party members must firmly remain committed to their ideals.

Ideological development refers to all the work carried out by the Party at the level of theory and belief to maintain creativity, cohesion and fighting strength. It is a fundamental as well as the leading factor of Party development. Ideological construction, in general, is to firm beliefs, ideology to build the Party, the theory to develop a strong Party.

We must first clarify the theoretical basis if we are to strengthen Ideological development. China is a socialist country where Marxist philosophy is the guiding ideology of our country and the ideological weapon to enrich the country and strengthen the army. Party members should firmly believe in Marxism, guard against the erosion of undesirable Western values and mantain cultural confidence. Secondly, we should vigorously promote the values of the Communist Party, 
that is, strengthen Party education and stay true to ideals and beliefs of Party members.

Second, organization building.

The correct organizational line guarantees the correct political path. To achieve the political tasks at the current historical stage, the Party must put organizational construction high on the agenda. Since the 18th National Congress, General Secretary Xi Jinping has attached particular importance to the Party's organizational construction and has made many important statements.

The strength of the Party originates from the organization, and organization building is an important foundation of the Party development, which serves the Party's political path. Organizational construction specifically includes the central and local organizations of the Party, Party members and cadres, and also includes the construction of democratic centralism and grassroots Party organizations. The Party organization system is the whole organized according to Party rules and regulations. Party membership construction is an important element of Party organization construction, which means that under the new socialist situation, it is necessary to adhere to Party membership standards, strengthen and Party membership education work, improve the quality of Party members and maintain the advanced nature of the Party organization.

Democratic centralism is the Party's organizational principle and fundamental organizational system. We should act in line with democratic centralism in organizational construction, that is, Party members obey the organization, subordinates obey their superiors, and localities obey the central government. Every Party member should be highly consistent with the Party Central Committee in thought as well as in action.

Within the organization, the cadres should be effectively assessed, rewarded and punished in a fair and impartial manner to encourage the initiative of Party members. The scientific way of assessment is to boldly select and adjust cadres. In addition, it is necessary to strengthen the leader team of the Party, expand the coverage of the Party organization, and effectively address the marginalization of the Party organization. To expand democracy within the Party and promote openness in Party affairs and government affairs. It is also necessary to unblock the channels for subordinates to make suggestions to superiors

Thirdly, working style construction.

The relationship between the Party and people is the core of the working style construction, the working style of the Party affects the relationship between the Party and the people as well as the people's hearts and minds. When the Party practice justice and people are satisfied, the Party and people can stick together through thick and thin. Party members and cadres in general are good, but we can also see some corruption scandals. To make people satisfied and get out of the historical cycle, it is necessary to fight against corruption and promote integrity, to use Xi Jinping Party building ideas to guide the construction of working style.

Party conduct, or the working style of the Party, is to ensure that the Party has always been the core of the leadership of the cause of socialism with Chinese characteristics, mainly including clean government and the fight against corruption, the Party style is a major issue related to the political security of the Party and the state, which shall not be obscure. We need to eliminate all corruption scandals, to set up a military order to walk the walk. The resurgence of corruption, not only deteriorates the political ecology, but also brings more serious damage to the Party and the people's hearts.

Party members and cadres must play an exemplary role, pursue a clean and honest government, adhere to high standards and keep the bottom line unified, with respect to face the power given by the people. To maintain political determination, we need to run the Party strictly and in accordance with the rules, fulfill the sacred duties conferred by the Party rules and regulations, focus on supervision and discipline accountability, deepen both temporary solutions and a permanent cure, innovate institutions and mechanisms, improve regulations and systems, as well as strengthen internal supervision. Beyond that, we give priority to discipline, persistently implement the spirit of the eight provisions of the central government, focus on addressing the climate of corruption around the public, resolutely curb the spread of corruption, build a loyal and clean discipline inspection and supervision team, thus making new headway in the improvement in the Party conduct, clean government construction and the fight against corruption.[1]

\section{THE CURRENT SITUATION OF PARTY DEVELOPMENT IN PUBLIC HOSPITALS}

The Covid-19 pandemic is the fastest spreading, most extensive, and most challenging public health emergency. Against this backdrop, it is very important to do a good job in Party development in public hospitals. Because only under the leadership of the Party can all medical and nursing staff better overcome the pandemic. However, in the actual work process, due to the lack of hospital political work, a series of problems have emerged within the hospital, which have seriously affected the healthy development of the work of public hospitals, and are divided as follows.

First, public hospital Party members are lack of study and a fair understanding of the Party rules and regulations and socialism. Medical and nursing workers should have the right attitude. On the one hand, they need to improve their medical skills, save lives and help the 
injured as their own duty, and serve the people heart and soul and use various treatment methods to make patients healthy again. On the other hand, they also learn socialist ideas and arm themselves with scientific ideas. However, the actual situation is that a considerable number of public hospital Party workers are negligent in their studies. Some hospital Party workers do not have a fair understanding of the Party rules and regulations as well as socialism, do not seriously study Party newspapers and magazines, do not pay attention to national events, neglect learning for a long time, do not strictly require themselves. Beyond that, they don't complete their work or even do the opposite, busy all day with trivial matters or face-saving projects, which is very wrong. The reason for their behaviors is that some health care workers think that Party development is optional and ignore the importance of the Party's leadership for the development of the hospital. The neglect of the Party development is not only detrimental to the hospital Party development, but also to the normal conduct of the hospital's medical and health services. For example, a hospital in Hangzhou enjoys close to 10,000 medical and nursing staff, but not a single Party member who really understands Marxist-related theories and has a professional background in political science. [2] In addition, due to the contradiction between work and study, [3] funding, space and other factors, the quality of "three meetings and one class" [4] conducted by the grassroots Party organizations in some public hospitals is far from meeting the requirements of comprehensive and strict governance of the Party. The scope of work is limited to conveying documents and holding meetings, resulting in unsatisfactory results of Party development in hospitals.

Second, the quality of the Party development workforce in public hospitals is low. China is a socialist country under the people's democratic centralism, and the people are masters of the country. Party development workers in public hospitals should have good ideals and beliefs, keep a clear mind in front of the great rights and wrongs, and establish a solid ideological defense line in the midst of various temptations and tests. Medical and nursing workers should adhere to the political stance and not pursue money superficially. Public hospitals are public welfare by nature. However, with the development of society and the influence of imported "money first" bad ideas, negative corruption and evil is spreading within public hospitals. Some doctors completely forget their identity as doctors and Party members, chasing after fame and profit, inducing patients to undergo unnecessary tests or surgeries, and even asking patients for red packets, directly leading to expensive medical care, and some patients' families become poor due to illness. Also according to Xinhua news, Anhui anti-corruption organs in 2018 revealed hundreds of corruption cases and bribery involving public hospitals, including 6 deans and 10 vice presidents above the second level. [5] The high incidence, multiplicity and frequency of negative corruption in public hospitals have weakened the relationship between the Party and the public, shaken the Party's ruling foundation and reduced the Party's credibility.

Third, the Party development in public hospitals is detached from the business. Hospital Party development work should be around a center, serve the overall situation, and complement health care services. However, the actual situation is that a considerable part of the public hospital Party development is detached from the business. Some hospital Party workers have misconceptions about the work of Party development in hospitals. They mistake the hospital system for administrative leadership and believe Party development is unnecessary. As for the fact that public hospitals tend to prioritize business while ignoring Party development, I believes that the defective hospital leadership system and Party development mechanism are responsible for it. It is true that the government has provisions on the terms of reference of the president and the Party committee of public hospitals, but these were formulated before the 18th National Congress, and they do not fit well with the "comprehensive strict governance of the Party" proposed by the 18th National Congress and the "adherence to the leadership of the Party in all work" proposed by the 19th National Congress.

\section{ENLIGHTMENT OF XI JINPING'S PHILOSOPHY ON PARTY DEVELOPMENT FOR PUBLIC HOSPITALS}

After the outbreak of the Covid-19 pandemic, General Secretary Xi personally commanded and deployed the pandemic, and put forward general requirements of " confidence, cooperation, scientific prevention and treatment, and precise measures" ,6]guiding major public hospitals and motivating the majority of medical and nursing staffs into active action, and the whole country worked together as a single team to start the national fight against the epidemic and made brilliant achievements. This shows that $\mathrm{Xi}$ Jinping's Party development ideology has practical guidance for Party development in public hospitals, which is described as follows.

The ideological development of medical Party members should be strengthened. General Secretary Xi Jinping pointed out that "ideological development is the fundamental of the Party. Without firm ideals and beliefs, we will lose our direction in the complex environment. We should draw the strength of faith from our Party inheritance, enhance the four consciousnesses, maintain the four self-confidences, and consciously be firm believers and faithful practitioners of the lofty ideals of communism." [7] In response to the phenomenon that Party members in public hospitals are negligent in learning and have little understanding of Party rules and 
regulations and socialism, the following measures should be taken: first, the Party development staff should be strengthened to learn about Marxism and theoretically understand what a socialist society is and how to build it. Secondly, communist values should be vigorously promoted among Party members, and various forms should be taken to enable hospital Party members to have a deeper understanding of Marxism and a firm ideal belief in building a socialist society.

Second, the organization of the Party building team in public hospitals should be strengthened. Regarding organizational construction, General Secretary Xi Jinping pointed out that "organizational construction is an important foundation of the Party's construction. The proletarian Party must become a unified whole and must be composed of the most thorough and determined advanced elements." [8] To address the phenomenon that the Party building workforce in public hospitals is detached from the business work, the following measures should be taken: first, improve and strengthen the Party development mechanism in public hospitals, and select qualified Party members for Party development. Secondly, give full play to the advantages of democratic centralism, democratic first and then centralized, and make concerted efforts to implement the Party building work into the business work. Once again, it is necessary to unblock the channels for subordinates to make suggestions to superiors and promote open Party affairs.

Third, the working style of the public hospital Party members group should be improved. General Secretary Xi Jinping pointed out that "we should improve Party conduct, build a clean government, further tighten the Party's discipline, and step up the establishment of a sound institutional mechanism to ensure that the Party governs scientifically, democratically, and in accordance with the law. All Party comrades should promote Party development with a more vigorous and energetic spirit."[9] In response to the phenomenon that Party development in public hospitals is detached from business work, the following measures should be taken: first, hospital Party members should play an exemplary role, adhere to high standards and keep the bottom line unified, maintain political determination, and perform the sacred duties given by the Party rules and regulations in accordance with the Party constitution. Secondly, a sound supervision mechanism should be established. Again, the unity of selection and strict management should be adhered to, i.e., Party personnel who really understand Marxist theory and have a professional background in political science should be selected, and we need to strengthen the daily supervision of Party members.

\section{CONCLUSION}

General Secretary Xi Jinping proposed the truth that the Chinese dream must be combined with the people's aspiration for a better life in order to succeed. [10] More convenient and better quality medical and health services are included in better life conditions. In order to achieve what people want, the majority of medical and nursing staff must consciously support the Communist Party of China, uphold the authority of the Party organization, adhere to the Party's leadership, and maintain a high degree of consistency with the Party Central Committee. Only by seriously doing a good job of Party development can public hospitals provide higher quality public health services to residents.

\section{REFERENCES}

[1] Xi Jinping. Speech at the sixth plenary session of the 18th Central Discipline Inspection Commission [J]. China Discipline Inspection and Supervision,2016(10):4-11.

[2] Golden Chuan, Problems and countermeasures of Party development in public hospitals, [J] Management Observation, 2016.

[3]Liu YJ,Wang HH. The theoretical connotation and practical implications of $\mathrm{Xi}$ Jinping's important discourse on the development of the Party's grassroots organizations $[\mathrm{J}]$. Journal of Theory,2021(01):24-31.

[4] Xi Jinping. Building a well-off society across the board and winning the great victory of socialism with Chinese characteristics in the new era [N]. People's Daily,2017-10-28(001).

[5] Shi Ping. Exploration of Xi Jinping's thought on Party development in the new era [J]. Journal of Jiamusi Vocational College,2019(07):17-19.

[6] Xi Jinping. Speech at the meeting on the deployment of the coordinated promotion of the prevention and control of the new crown pneumonia epidemic and economic and social development [N]. People's Daily,2020-02-24(002).

[7] Xi Jinping. Use the red resources, inherit the red gene and pass on the red rivers and mountains for generations [J]. Taiwan Voice,2021(11):10-21.

[8] Xi Jinping. Implementing the Party's organizational line in the new era and constantly building the Party stronger [J]. Pioneer, 2020(08):4-7.

[9] Xi Jinping. Comprehensively implement the spirit of the 18th Party Congress to highlight the work of six aspects [J]. Seeking truth, 2013(01):3-7.

[10] Xi Jinping. No power struggle, no "house of cards" in China's anti-corruption campaign: speech at the joint welcome Party of local government and U.S. friendship groups in Washington State $[\mathrm{J}]$. China Industry and Economy,2015(10):14-23. 